\title{
Performance of Back Cross Progeny from Hansli Male and Coloured Broiler Female Chicken
}

\author{
Sagarika Behera $^{1 *}$, Bhagirathi Panigrahi ${ }^{1}$, Chitta Ranjan Pradhan ${ }^{1}$, \\ Nrusingha Behura ${ }^{2}$, Niranjan Panda ${ }^{3}$ and Jessy Bagh ${ }^{1}$
}
${ }^{1}$ Department of Livestock Production and Management, College of Veterinary Science and Animal Husbandry, Orissa University of Agriculture and Technology, Bhubaneswar-751003, Odisha, India
${ }^{2}$ Department of Poultry Science, ${ }^{3}$ Department of Animal Nutrition, College of Veterinary Science and Animal Husbandry, Orissa University of Agriculture and Technology, Bhubaneswar-751003, Odisha, India
*Corresponding author

\section{A B S T R A C T}

\section{Keywords}

Three-way cross, Growth performance, Linear body measurements, Hansli, Coloured broiler.

Article Info

Accepted:

26 June 2017

Available Online:

10 July 2017
Performances of two genotypes of broiler chicken were evaluated under intensive system of management for different growth and carcass traits. The genotypes were (i) Group-I: Colored synthetic broiler (CSML $\hat{\sigma}$ x CSFL + ) crosses; (ii) Group-II: (Hansli x CSML) $\hat{\sigma}$ $\mathrm{x}$ CSML + crosses. Significantly ( $\mathrm{p} \leq 0.05$ or 0.01 ) higher body weight and weight gain was recorded in group-I at every stage from $1^{\text {st }}$ to 8 week. Chicks in group-II showed significantly higher values for FCR at $2^{\text {nd }}, 3^{\text {rd }}$, and $4^{\text {th }}$ week. Chicks in group-I showed higher feed intake in every week compared to those in group-II and differences were found significant $(\mathrm{P} \leq 0.05$ or 0.01$)$ at $4^{\text {th }}, 5^{\text {th }}, 6^{\text {th }}, 7^{\text {th }}$ and $8^{\text {th }}$ week of age. Group-I showed mortality of $1.66 \%$ where as in group-II had zero mortality. Chicks in group-II showed significantly $(\mathrm{p} \leq 0.01$ or $\mathrm{p} \leq 0.05))$ greater breast angle and beak length, while the chicks in group-I showed significantly ( $\mathrm{p} \leq 0.01)$ greater body length, body girth, shank length, shank width and keel length at $6^{\text {th }}$ week. At $8^{\text {th }}$ week, chicks in group-II showed significantly ( $\mathrm{p} \leq 0.05$ or 0.01 ) lower values compared to those in group-I in respect of all parameters except for beak length and breast angle which was not differ significantly ( $\mathrm{p} \geq 0.05)$.

\section{Introduction}

Commercial poultry production has gained popularity since last two decades in India. Poultry has adapted to most areas of the world and has a high economic value as well as rapid generation time (Smith, 1990). It is a means of bridging the ever widening gap of protein insufficiency (Ughene et al., 2005). The rapid growth of the human population in India has led to a relatively high demand for protein. Meat and eggs are among the most important forms of animal protein in economically developed and developing areas of the world. Poultry meat is the cheapest source of protein compared to other animal protein forms and probably most consumed. Medical research also indicates that poultry meat has lower cholesterol content in contrast to red meat (Khatun, 2012). Among the various aspects in poultry science, improvement in genetic makeup by various breeding methods is an important aspect to improve feed efficiency, egg production and 
egg quality. Genetic progress can be accomplished either by selection or crossbreeding. Crossbreeding of the indigenous stock with exotic commercial birds will take advantage of artificial selection for productivity in the exotic birds and natural selection for hardiness in the native birds (Adebambo et al., 2011). Cross breeding can be carried out as two-way, three-way or fourway crosses, back crosses or rotational crosses. This system also maximizes the expression of heterosis, or hybrid vigour in the cross, normally reflected in improved fitness characteristics (Hoffmann, 2005). To retain heterosis in the maternal traits, threeway or four-way crossing has to be applied. In three-way crosses the crossbred chicken is mated with a third line. A good combining ability resulting from a choice of the best performing crossbred could lead to the production of birds that will be better in growth rate, efficiency of feed conversion and reproductive traits, without sacrificing adaptation to the local environment, thereby resulting in reduced cost of production. The breeding objectives should focus on the development of a chicken crossbred that would be adaptable to the local climatic conditions and be suitable for backyard as well as commercial rearing, while retaining the characters of the indigenous chicken such as plumage colour and meat quality. In view of the afore said, the present study has been undertaken to study the broiler traits of crosses of native and coloured parent line in respect of their growth performance, linear body measurement and mortality rate.

\section{Materials and Methods}

The experiment was carried out in the Poultry Complex of the faculty of Veterinary Science and Animal Husbandry, Orissa University of Agriculture and Technology, Bhubaneswar. Performance of two genotypes of broiler chicken was utilized in the study. The genotypes were; (i) Group-I: Colored synthetic broiler (CSML $\hat{0} \mathrm{x}$ CSFL $q$ ) crosses; (ii) Group-II: (Hansli x CSML) $\hat{\sigma} \mathrm{x}$ CSML $q$ crosses. Adult Colour synthetic male line (CSML) males and Colour synthetic female line (CSFL) females at the age of 40 weeks were housed in breeding pens in the ratio 1:7. Seven CSML males and fifty CSFL females were used for the cross breeding. Simultaneously (Hansli X CSML) males and as well as CSML females were maintained in the same ratio to obtain pure eggs. Eggs from two genetic groups were collected daily for ten days, identified appropriately with markers and set in the incubator. A total of 120 straight run day-old chicks, 60 each of the 2 genotype groups were taken and divided into 3 replicates each comprising 20 chicks. The chicks were numbered by wing band, weighed and randomly distributed in separate pens according to treatments and birds were vaccinated against various diseases. The chicks were brooded up to three weeks with a brooding space of $0.5 \mathrm{ft}^{2} /$ chick. Adlibitum feeding was done and the amount consumed was recorded daily. Experimental chickens were fed with a standard broiler starter ration containing $22 \%$ crude protein and $3150 \mathrm{kcal} /$ $\mathrm{kg}$ ME for four weeks followed by a finisher diet containing $20 \%$ crude protein and 3150 $\mathrm{kcal} / \mathrm{kg} \mathrm{ME}$ from fifth week till the end of the experiment at eight weeks. The composition of ration has been given in table 1 .

Live weight of mixed sexes was recorded at day-old followed by weekly intervals up to 8 weeks of age using a digital electronic balance nearest to $1.0 \mathrm{~g}$ accuracy. The birds were weighed in the morning before supplying the feed. Weekly cumulative body weight gain was calculated by subtracting the day-1 average body weight from the weekly average body weight of the respective week. The feed intake was recorded replicate-wise on weekly basis by subtracting the left over feed at the end of the week from the total feed offered during the week. Cumulative feed intake (g/bird) was calculated by dividing 
total feed consumed by the bird up -to a particular week from number of birds. Feed conversion ratio (FCR) was calculated from cumulative BW gain and cumulative feed intake. Mortality of the chick was recorded daily replicate-wise.

The mortality of all the chicks of the replicate groups belonging to a treatment were added and expressed on weekly basis. All body linear measurements were determined in two genotypes at 6 week and 8 week using measuring tapes (calibrated in centimetres) except breast angle which was measured by goniometer as described below:

Beak length: Distance between the base and tip of the beak

Head width: The widest region in the head.

Breast angle: A goniometer was placed at $1 \mathrm{~cm}$ from the extreme of the tool had to be adjusted on the left breast and the mobile arm, on the right breast and expressed as degree.

Shank length: Length of the tarso meta-tarsus from the hock joint to the meta- tarsal pad of the bird.

Shank width: Diameter of the tarso metatarsus just below the spur of the individual bird.

Body length: Distance from the tip of the beak through the body trunk to the tail.

Height of the bird: Measured from tip of the beak to the tip of the middle toe. Body girth: Circumference of breast region of the bird. Keel length: It was measured from the chest bone to the end towards the abdomen region. The data obtained from the study were statistically analyzed according to Snedecor and Cochran (1994). The data were analyzed for $t$ - test to test the difference between means wherever necessary.

\section{Results and Discussion}

\section{Body weight and weight gain}

The mean weekly body weights and weight gain for the chicks in the two groups are presented in table 2. The body weight of group-I were significantly $(p \leq 0.01)$ higher than that of group-II for all ages except day old body weight and also group-I chicks recorded significantly $(\mathrm{p} \leq 0.05$ or 0.01$)$ higher gains compared to those in group-II at every stage from $1^{\text {st }}$ to $8^{\text {th }}$ week because group-I is a cross of broiler parent line and native chicken (Hansli). Hansli being a local chicken has slower rate of growth as compared to broiler parent lines, as reported by Ekka et al., (2016).

\section{Feed intake and FCR}

The mean weekly cumulative feed intake and mean weekly cumulative FCRs for the chicks in the two groups are presented in table 3 . The chicks in group-I showed higher feed intakes and lower FCRs in every week compared to those in group-II. There was no significance difference $(\mathrm{P} \geq 0.05)$ in cumulative feed intake between the group-II and group-I at $2^{\text {nd }}, 3^{\text {rd }}$ and $4^{\text {th }}$ week of age. However the cumulative feed intake for $1^{\text {st }}, 5^{\text {th }}, 6^{\text {th }}, 7^{\text {th }}$ and $8^{\text {th }}$ week of group-II was significantly $(\mathrm{P} \leq 0.05$ or 0.01$)$ lower than the group-I. The cumulative feed consumption up to $8^{\text {th }}$ week of group-I was significantly $(\mathrm{p} \leq 0.01)$ higher $(3955.73 \mathrm{~g})$ than the group-II (3112.32g). Similar feed consumption of 3717.83 and $2860.53 \mathrm{~g}$ up to 8 weeks of age have been reported by Howlider (2001) for Redbro X Local Naked neck and Local Naked neck X Redbro crosses, respectively. Ekka et al., (2016) reported feed consumption of $2539.14 \mathrm{~g}$ up to $8^{\text {th }}$ week of age, which is lower than that of $8^{\text {th }}$ week fed Nwachukwu consumption of groupII. Broilers are selected for high growth, high feed intake and better feed conversion efficiency. 
The cross under study is a back cross of Hansli X CSML with CSML for which the feed consumption could have increased. The chicks in group-II showed significantly $(\mathrm{P} \leq 0.01)$ higher FCRs at $2^{\text {nd }}, 3^{\text {rd }}, 4^{\text {th }}$ and $5^{\text {th }}$ week as compared to those in group-I. Lower FCR values of group-I could be due to better feed conversion efficiency as it is a cross of two broiler parent lines. The group-II which derived $25 \%$ germplasm from native chicken variety (Hansli) which has poor feed conversion efficiency (3.26) as reported by Ekka et al., (2016), could have contributed to the higher FCR values during the said period. Similar $8^{\text {th }}$ week FCR values for improved and native crosses, ranging from 3.2 to 3.8 have been reported by et al., (2006) and Howlider (2001).

\section{Mortality}

Among the genotypes under study, group-I has $1.66 \%$ mortality and group-II had zero mortality which could be due to group-II involves of $25 \%$ germplasm from Native chicken variety that is Hansli. So, that better adaptability to local climatic conditions. Similar results of zero mortality for local fayoumi X improved RIR were reported by Ojo et al., (2011). Further Jha et al., (2012); Ojo et al., (2012) also reported $8.3 \%$ and $<2 \%$ of mortality for Dahlem Red X Desi and native chicken $\mathrm{X}$ Dominant Black crosses during 0-8 weeks of age. From the findings of previous works it is found that the mortality in different genotypes as recorded in the present investigation were lower than or similar to earlier reported values for improved and their crosses. The mortality in chicks is influenced by several factors including the management practices. Therefore, a wide variation in mortality for the same genotype has been reported by different workers.

Table.1 Composition of rations

\begin{tabular}{|l|l|l|l|}
\hline Sl.No. & Ingredients(kg) & Starter mash & Finisher mash \\
\hline 1 & Maize & 60 & 60 \\
\hline 2 & Soya bean meal & 34 & 30 \\
\hline 3 & De-oiled rice bran & 2.5 & 1.5 \\
\hline 4 & Vegetable oil(lit) & 3.5 & 5.5 \\
\hline 5 & Mineral mixture & 3 & 3 \\
\hline \multicolumn{2}{|l}{} \\
\hline 1 & Nutritive value & 22 & 20 \\
\hline 2 & $\mathrm{CP} \%$ & 3150 & 3150 \\
\hline
\end{tabular}

Table. 2 Weekly body weight (g) and weight gain of chicks

\begin{tabular}{|c|c|c|c|c|c|c|}
\hline & \multicolumn{3}{|c|}{ Body weight } & \multicolumn{3}{c|}{ Weight gain } \\
\hline Age (Weeks) & Group-I & Group-II & Significance & Group-I & Group-II & Significance \\
\hline 0 day & $41 \pm 0.37$ & $39.82 \pm 0.52$ & NS & - & - & - \\
\hline $1^{\text {st }}$ & $101.07 \pm 1.68$ & $85.74 \pm 1.78$ & $* *$ & $60.07 \pm 0.63$ & $45.92 \pm 0.63$ & $* *$ \\
\hline $2^{\text {nd }}$ & $204.17 \pm 4.57$ & $159.81 \pm 4.39$ & $* *$ & $163.16 \pm 3.91$ & $120.00 \pm 2.75$ & $*$ \\
\hline $3^{\text {rd }}$ & $363.70 \pm 8.06$ & $272.86 \pm 9.57$ & $* *$ & $316.64 \pm 7.16$ & $233.03 \pm 10.56$ & $*$ \\
\hline $4^{\text {th }}$ & $537.02 \pm 11.52$ & $406.45 \pm 12.86$ & $* *$ & $487.07 \pm 11.73$ & $366.63 \pm 13.49$ & $* *$ \\
\hline $5^{\text {th }}$ & $699.80 \pm 15.86$ & $524.8 \pm 18.03$ & $* *$ & $647.14 \pm 0.81$ & $484.98 \pm 18.04$ & $* *$ \\
\hline $6^{\text {th }}$ & $873.80 \pm 20.87$ & $649.24 \pm 19.86$ & $* *$ & $818.24 \pm 17.20$ & $609.42 \pm 21.41$ & $*$ \\
\hline $7^{\text {th }}$ & $1074.80 \pm 24.65$ & $804.33 \pm 24.46$ & $* *$ & $1015.89 \pm 8.49$ & $764.52 \pm 9.56$ & $* *$ \\
\hline $8^{\text {th }}$ & $1354.39 \pm 29.35$ & $995.47 \pm 28.96$ & $* *$ & $1290.82 \pm 12.72$ & $955.65 \pm 18.34$ & $* *$ \\
\hline
\end{tabular}

* Mean values differ significantly $(\mathrm{p} \leq 0.05), * *$ Mean values differ significantly $(\mathrm{p} \leq 0.01)$ 
Table.3 Weekly cumulative feed intake and weekly cumulative FCR of chicks

\begin{tabular}{|c|c|c|c|c|c|c|}
\hline \multirow{2}{*}{ Age(weeks) } & \multicolumn{3}{|c|}{ Weekly cumulative feed intake } & \multicolumn{3}{c|}{ Weekly cumulative FCR } \\
\cline { 2 - 7 } & Group-I & Group-II & Significance & Group-I & Group-II & Significance \\
\hline $1^{\text {st }}$ & $94.17 \pm 4.17$ & $73.34 \pm 1.67$ & $*$ & $1.57 \pm 0.09$ & $1.60 \pm 0.06$ & NS \\
\hline $2^{\text {nd }}$ & $379.00 \pm 19.52$ & $314.67 \pm 4.67$ & NS & $2.32 \pm 0.07$ & $2.62 \pm 0.07$ & $* *$ \\
\hline $3^{\text {rd }}$ & $777.25 \pm 18.64$ & $687.50 \pm 16.33$ & NS & $2.46 \pm 0.04$ & $2.96 \pm 0.07$ & $* *$ \\
\hline $4^{\text {th }}$ & $1158.30 \pm 22.14$ & $1053.50 \pm 19.04$ & NS & $2.38 \pm 0.06$ & $2.88 \pm 0.05$ & $* *$ \\
\hline $5^{\text {th }}$ & $1725.04 \pm 23.75$ & $1500.50 \pm 15.18$ & $*$ & $2.67 \pm 0.04$ & $3.10 \pm 0.06$ & $* *$ \\
\hline $6^{\text {th }}$ & $2412.31 \pm 44.01$ & $1930.52 \pm 34.91$ & $* *$ & $2.95 \pm 0.06$ & $3.17 \pm 0.12$ & $\mathrm{NS}$ \\
\hline $7^{\text {th }}$ & $3073.72 \pm 55.22$ & $2425.65 \pm 37.32$ & $* *$ & $3.03 \pm 0.07$ & $3.17 \pm 0.07$ & $\mathrm{NS}$ \\
\hline $8^{\text {th }}$ & $3955.73 \pm 74.01$ & $3112.32 \pm 26.35$ & $* *$ & $3.07 \pm 0.06$ & $3.26 \pm 0.08$ & $\mathrm{NS}$ \\
\hline
\end{tabular}

* Mean values differ significantly $(\mathrm{p} \leq 0.05), * *$ Mean values differ significantly $(\mathrm{p} \leq 0.01)$

Table.4 Body linear measurements of chicks

\begin{tabular}{|c|c|c|c|c|c|c|}
\hline \multirow{2}{*}{ Parameter } & \multicolumn{4}{|c|}{ 6th week } & \multicolumn{2}{c|}{ 8th wk } \\
\cline { 2 - 7 } & Group-I & Group-II & Significance & Group-I & Group-II & Significance \\
\hline Breast angle & $50.65 \pm 0.21$ & $55.54 \pm 0.24$ & $* *$ & $59.99 \pm 0.35$ & $59.00 \pm 0.27$ & NS \\
\hline Beak length & $2.63 \pm 0.08$ & $3.00 \pm 0.02$ & $*$ & $3.38 \pm 0.07$ & $3.34 \pm 0.33$ & NS \\
\hline Head length & $5.38 \pm 0.10$ & $4.07 \pm 0.68$ & $* *$ & $6.12 \pm 0.05$ & $4.57 \pm 0.07$ & $* *$ \\
\hline Head width & $2.86 \pm 0.06$ & $2.31 \pm 0.02$ & $*$ & $3.50 \pm 0.08$ & $2.31 \pm 0.05$ & $* *$ \\
\hline Body length & $32.92 \pm 0.30$ & $28.3 \pm 0.25$ & $* *$ & $36.55 \pm 0.31$ & $34.41 \pm 0.44$ & $* *$ \\
\hline Body girth & $28.80 \pm 0.18$ & $23.54 \pm 0.14$ & $* *$ & $34.38 \pm 0.20$ & $30.05 \pm 3.94$ & $* *$ \\
\hline Shank length & $8.23 \pm 0.17$ & $7.25 \pm 0.07$ & $* *$ & $10.90 \pm 0.12$ & $8.90 \pm 0.12$ & $* *$ \\
\hline Shank width & $1.76 \pm 0.04$ & $1.45 \pm 0.01$ & $* *$ & $2.12 \pm 0.04$ & $1.60 \pm 0.02$ & $* *$ \\
\hline Keel length & $9.15 \pm 0.12$ & $8.13 \pm 0.05$ & $* *$ & $12.33 \pm 0.15$ & $9.86 \pm 0.13$ & $* *$ \\
\hline Body height & $32.63 \pm 0.30$ & $29.28 \pm 0.17$ & $* *$ & $38.65 \pm 0.20$ & $34.53 \pm 0.50$ & $* *$ \\
\hline
\end{tabular}

*Mean values differ significantly $(\mathrm{p} \leq 0.05), * *$ Mean values differ significantly $(\mathrm{p} \leq 0.01)$

\section{Body linear measurements}

The mean body linear measurements for the chicks in the two groups recorded at $6^{\text {th }}$ and $8^{\text {th }}$ week are presented in table 4. All parameters except beak length are significantly $(\mathrm{p} \leq 0.05)$ lower in group-II than group-I. The group-I is a cross of broiler parent lines which are selected over generations for higher breast angle, keel length, and shank length.

That could be the reason for obtaining higher values for these parameters in group-I than group-II which is a cross involving native population. Chicks in group-I showed lower values $(\mathrm{p} \leq 0.01$ or 0.05$)$ for breast angle and beak length at $6^{\text {th }}$ week, while at $8^{\text {th }}$ week, these differences were found nonexistent. It might be due to differences between the two genotypes in growth pattern of these two organs. Ekka et al., (2016) found higher breast angle in the CSML and Hansli x CSML cross than the Hansli breed. Similarly, they also reported higher beak length, head width, body length, body girth and all other body measurements in CSML than the Hansli and Hansli x CSML crosses. It may be due to the fact that CSML has higher body weight throughout the experimental period of 8 weeks and has been developed from two broiler parent lines.

In conclusion, Group-I (CSML X CSFL) was found to have superior growth performance than group-II (Hansli X CSML) X CSML. 


\section{Acknowledgments}

The authors are thankful to Dean, College of Veterinary Science and Animal Husbandry and Department of Poultry Science for providing necessary facilities to conduct the research work. Funds to carry out this research work were provided by the Department of Livestock Production and Management, College of Veterinary Science and Animal Husbandry, Orissa University of Agriculture and Technology.

\section{References}

Adebambo, A.O., Ikeobi, CON., Ozoje, M., Oduguwa, O.O. 2011. Combining abilities of growth traits among pure and crossbred meat type chickens. Archivos de zootecnia.,60 (232): 953963.

Ekka, R., Behura, N.C., Samal, L., Nayak, G.D., Pati, P.K., Mishra, P.K. 2016. Growth performance and linear body measurements of Hansli, CSML and Hanslix CSML cross under intensive system of rearing. M.V.Sc. thesis submitted to Odisha University of Agriculture and Technology, Odisha.

Hoffman, I., Siewerdt, F., Manzella, D. 2005. Research and investment - Challenges and options for sustainable use of poultry genetic resources. World's poultry science journal.

Howlider, M.A.R. 2001. A report on effect of the dwarf gene on the performance of broiler strain in hot humid tropics. Bangladesh Agricultural Research Council, Farm Gate, Dhaka

Jha, D.K, Prasad, S, Soren, S.K., Mahto, D. 2012. Performance of Vanaraja birds under deep litter system of management. Indian Veterinary Journal 89(1): 75-76.

Khatun, A. 2012. Study on growth and meat yield characteristics of different line crosses of chicken, (Doctoral dissertation).

Nwachukwu, E. N., Ibe, S. N., Ejekwu, K., One, U. K. 2006. Evaluation of growth parameters of main and reciprocal crossbreed normal, naked neck and frizzle chickens in a humid tropical environment, Journal of animal and veterinary advances, 65(7): 542-546.

Ojo- Sola, F. E., Ayorinde, K. L. 2011. Evaluation of reproductive performance and egg quality traits in progenies of dominant black strain crossed with Fulani Ecotype chicken, Journal of Agricultural Science, 3(1): 258.

Smith AJ. 1990. The tropical Agriculturalist: Poultry Macmillan Press, London. 217.

Snedecor, G.W., Cochran, W.G. (1994). Statistical methods 8th. Ed. Ames: The lowa state university press.

\section{How to cite this article:}

Sagarika Behera, Bhagirathi Panigrahi, Chitta Ranjan Pradhan, Nrusingha Behura, Niranjan Panda and Jessy Bagh. 2017. Performance of Back Cross Progeny from Hansli Male and Coloured Broiler Female Chicken. Int.J.Curr.Microbiol.App.Sci. 6(7): 2739-2744. doi: https://doi.org/10.20546/ijcmas.2017.607.384 